\title{
QUALITY NEWS DAN POPULAR NEWS SEBAGAI TREND PEMBERITAAN MEDIA ONLINE \\ (Studi Deskriptif Kualitatif Trend Pemberitaan Quality News dan Popular News pada Media Online Nasional di Indonesia Periode 2016)
}

\author{
Oleh: Rani Dwi Lestari \\ (Fakultas Ilmu Komunikasi dan Multimedia Universitas Mercu Buana Yogyakarta) \\ E-mail: aieramaharani@gmail.com
}

\begin{abstract}
Abstrak
Pesatnya perkembangan media online khususnya portal berita di Indonesia, memunculkan beragam informasi yang disajikan untuk masyarakat. Portal media online bahkan terus bermunculan seiring pesatnya perkembangan pasar pengakses informasi melalui fasilitas internet. Ramainya portal media online yang bermunculan ini sekaligus juga memunculkan gaya penyajian berita yang berbeda-beda pada tiap kanal. Namun demikian, tidak seluruhnya mampu menyajikan pemberitaan sesuai dengan kaidah karya jurnalistik yang selama ini berlaku. Tulisan ini akan mencoba mendiskripsikan pola penyajian berita di situs-situs berita online Indonesia sebagai trend pemberitaan. Pada bagian awal, tulisan ini akan membahas perkembangan dan karakteristik media online di Indonesia. Bagian kedua akan dibahas mengenai pola-pola penyajian pemberitaan media online dan di bagian selanjutnya akan dipaparka trend pemberitaan media online yang merujuk pada Quality News dan Popular News.
\end{abstract}

Kata kunci: Media Online, Berita, Internet, Trend Pemberitaan, Quality News, Popular News.

\begin{abstract}
The rapid development of online media, especially news portals in Indonesia, raises a variety of information presented to the community. Online media portals even continue to emerge as the rapid development of market accessing information through internet facilities. The bustling online media portal that sprung this as well as raises the style of presenting different news on each channel. However, not entirely capable of presenting the news in accordance with the rules of journalism work that has been applied. This paper will try to describe the pattern of news presentation on online news sites Indonesia as a news trend. In the beginning, this article will discuss the development and characteristics of online media in Indonesia. The second part will be discussed about the presentation patterns of online media coverage and in the next section will be presented online media news trend that refers to Quality News and Popular News.
\end{abstract}

Keywords: Online Media, News, Internet, News Trend, Quality News, Popular News.

\section{A. Pendahuluan}

Pemberitaan di media massa khususnya media online kini bukan lagi menjadi alternatif bagi masyarakat untuk mendapatkan sebuah informasi. Dalam perkembangannya, media online justru dijadikan pilihan utama masyarakat dalam mendapatkan banyak hal termasuk diantaranya adalah berita. Ini berkorelasi pula dengan tingginya jumlah pengguna internet di Indonesia yang mencapai angka 38 juta lebih dengan penetrasi 
mencapai 15 persen pada tahun 2014. Dimana rata-rata pengguna internet di Indonesia menghabiskan waktu hampir 3 jam setiap harinya untuk terkoneksi dan berselancar di internet. Kehadiran internet ini menjadikan media tradisional seolah-olah mendapatkan pesaing baru dalam mendistribusikan berita. ${ }^{1}$

Dalam mendistribusikan beritanya, media online menggunakan banyak cara untuk memancing "klik" pembaca. Kerap kita temui ragam keunikan media online yang sebelumnya jarang diaplikasikan di media konvensional seperti korandiantaranya: ${ }^{2}$

1. Unlimited Space. Jurnalistik online memungkinkan halaman tak terbatas. Ruang bukan masalah. Artikel dan berita bisa selengkap dan sepanjang mungkin, tanpa batas.

2. Audience Control. Jurnalistik online memungkinkan pembaca lebih leluasa memilih berita/informasi.

3. Non-Lienarity. Dalam jurnalistik online masing-masing berita berdiri sendiri sehingga pembaca tidak harus membaca secara berurutan.

4. Storage and Retreival. Jurnalistik online memungkinkan berita "abadi", tersimpan dan bisa diakses kembali dengan mudah kapan dan di mana saja.

5. Immediacy. Jurnalistik online menjadikan informasi bisa disampaikan secara singkat cepat dan langsung.

6. Multimedia Capability. Jurnalistik online memungkinkan sajian berita berupa teks, suara, gambar, video dan komponen lainnya sekaligus.

7. Interactivity. Jurnalistik online memungkinkan interaksi langsung antara redaksi dengan pembaca seperti melalui kolom komentar dan social media sharing.

Selain memiliki karakternya sendiri, media online juga dianggap memiliki kekuatan pembeda dengan media lain yakni pada speed atau kecepatan. Prinsip real time online inilah yang menyorot perhatian khalayak untuk lebih memilih media online dalam hal update informasi. Kondisi ini pada akhirnya mendatangkan konsekuensi logis bahwa media massa online harus berlomba-lomba bersaing dengan media lain terutama dengan media sejenis dalam merebut perhatian khalayak.

Benar adanya apa yang diungkapkan Luwi Ishwara ${ }^{3}$ bahwa perubahan-perubahan terutama di bidang teknologi internet mengakibatkan tugas media menjadi lebih berat karena berita berubah begitu cepat. Cara pengumpulan dan penyajian berita pun berubah, kini lebih cepat, lebih bebas dan lebih murah - faster, looser and cheaper. Jurnalisme berada dalam keadaan membingungkan. Perubahan teknologi telah begitu cepat sehingga pangsa pasar media menurun dan makin sempit. Sementara itu tekanan untuk menjalankan operasi secara efisien justru semakin kuat. Dalam keputusasaan untuk menarik masyarakat peminat, terkadang pers bergerak ke arah sensasi, hiburan dan opini. Akibatnya bagi jurnalisme adalah dilanggarnya etika pers, merosotnya audiences dan kepercayaan masyarakat.

Kehadiran internet menjadikan setiap jam dan bahkan setiap menit, berita bisa diunggah tanpa kesulitan teknis yang berarti. Cukup dengan sebuah gadget telpon selular,

\footnotetext{
${ }^{1}$ Nasrullah, Rulli. 2016. Media Sosial: Perspektif Komunikasi, Budaya dan Sosioteknologi. Simbiosa Rekatama Media: Bandung. (hal 12)

${ }^{2}$ Sabil Iskandar, Dudi; Rini Lestari. 2016. Mitos Jurnalisme. Penerbit Andi: Yogyakarta.

${ }^{3}$ Ishwara, Luwi. (2014). Jurnalisme Dasar. Kompas Media Nusantara: Jakarta. Hal 14
} 
Diterbitkan oleh Program Studi IImu Komunikasi

Universitas Ahmad Dahlan Yogyakarta

jurnalis di lapangan bisa terkoneksi dengan ruang redaksi, dan hanya dengan tiga paragraf sebuah berita bisa dikabarkan ke khalayak secara instan. Perkembangan sebuah peristiwa bisa diperbarui setiap saat dengan menambah satu atau dua paragraf baru. Muncullah trend lain yang melanda jurnalisme online salah satunya yakni dari segi konten pemberitaan.

Jika dibandingkan dengan media konvensional, media online memiliki ruang yang tidak terbatas. Ini tentu berbeda dengan keterbatasan yang dimiliki halaman media cetak atau frekuensi milik media elektronik. Media online dengan karakter Storage and Retreival memungkinkan penyimpanan dokumen berita tanpa batas dan bisa diakses kembali ketika dibutuhkan. Konsekuensi dari kelebihan yang dimiliki media online tersebut adalah munculnya kanal-kanal pemberitaan dalam satu portal media online. Kanal-kanal tersebut mengelompokkan berbagai jenis konten berita yang disajikan oleh tiap-tiap media online. Konten berita tersebut bisa sangat beragam dan tak terbatas jumlahnya. Keragaman konten ini pula yang seringkali menjadi daya tarik media online bagi khalayak.

Kemunculan ragam konten berita tersebut sekaligus memunculkan pertanyaan yang lebih mendalam seputar isu yang diangkat dalam setiap pemberitaan media online. Jika diamati secara makro, media online cenderung menyiarkan ragam berita tentang selebritas dunia hiburan dan politik yang menekankan pada karakter dan aspek personal kehidupan mereka. Pada saat yang sama, trend tersebut disertai trend menurunnya jumlah berita-berita yang berbasis pada isu, masalah masalah sosial, dan kebijakan. Topik dan judul sensasional yang mengarah pada sisi kehidupan pribadi narasumber seolah dikupas habis untuk menjadi konsumsi publik dengan tidak mengindahkan kaidah dan kode etik jurnalistik.

Hal inilah yang juga menjadi salah satu pemikiran Erman Anom ${ }^{4}$, bahwa belum semua pers Indonesia dikelola secara profesional dan mampu melakukan pemberitaan yang bertanggungjawab. Banyak perusahaan pers yang mengelarkan berita-berita gosip dan pernyataan yang tidak benar atau bias. Dilihat dari sisi lain kepentingan masyarakat, tentu saja pers yang tidak berkualitas akan sangat merugikan karena tidak mendidik masyarakat dan sebagai pembentuk pendapat publik.

Jika dipetakan secara lebih rinci lagi, trend pemberitaan dalam media online di Indonesia terbagi dalam dua kategori berbeda yakni Quality News dan Popular News. Konsep Quality News menekankan pada pemberitaan yang berkualitas. Kualitas disini bisa ditakar dari sisi teknikalitas penulisan yang sesuai dengan kaidah jurnalistik, maupun dari sisi isu yang diangkat yang menyangkut kepentingan publik. Sementara, Popular News lebih menekankan pada pemberitaan-pemberitaan populer dimana dari sisi teknikalitas tidak selalu memperhatikan kaidah jurnalistik, namun hanya mengutamakan sensasionalitas pemberitaan. Di sisi lain, isu yang diangkat lebih banyak pada personalisasi kepentingan privat yang jauh dari kepentingan publik.

Adanya kecenderungan pemberitaan inilah yang menarik untuk dikaji terkait bagaimana sebenarnya bentuk-bentuk trend pemberitaan di media online Indonesia khususnya dalam kurun waktu tahun 2016 dikaitkan dengan konsep Quality News dan Popular News? Pertanyaan tersebut yang akan coba dianalisis dan dijawab dalam penelitian ini

${ }^{4}$ Anom, E. (2011), "Wajah Pers Indonesia 1999-2011”, Jurnal Komunikasi, Malaysian Journal of Communication, 27 (1): 101-114. 
dengan menggunakan metode deskriptif kualitatif. Dimana objek dalam penelitian ini adalah media online nasional di Indonedia yakni Tribunnews.com, dan Kompas.com. Sampel yang digunakan dalam penelitian ini adalah berita-berita di media online selama periode 2016 yang dipilih dan digolongkan dalam Quality News dan Popular News

\section{B. Konsep Quality News dan Popular News dalam Pemberitaan Media Online}

\section{Konsep Quality News}

Konsep mengenai berita berkualitas atau quality news dapat dilihat dari dua aspek. Pertama dari segi teknikalitas, berita yang berkualitas minimal harus mengikuti beberapa kaidah-kaidah dan prinsip jurnalistik. Meminjam konsep yang dipakai oleh tim digijournalism ${ }^{5}$, terdapat enam (6) dimensi yang digunakan untuk melihat aspek teknikalitas, yaitu: 1) Aktualitas, 2) Konsistensi Teknis, 3) Akurasi Penulisan, 4) Akuntabilitas penyebutan sumber, 5) Transparansi, 6) Kelengkapan berita.

Keenam dimensi tersebut pada dasarnya beririsan dengan gagasan McQuail mengenai salah satu cara untuk melihat profesionalitas media dengan mengukur objektifitas media yang mencerminkan aktualisasi nilai dan presentasi media. Dari sana kita dapat melihat kualitas contentmedia melalui berita (Rahayu.ed. 2006: 6-7).

Skema yang dibangun oleh Westerstahl tahun 1983 digunakan untuk melakukan penelitian mengenai objektifitas pemberitaan media massa (Rahayu.ed. 2006: 8-9). Dalam penelitian objektifitas oleh McQuail:

Aspek kognitif berita sangat terkait dengan faktualitas. Secara sederhana, faktualitas dapat diartikan sebagai kualitas informasi yang dikandung oleh suatu berita. Faktualitas memiliki tiga aspek utama, yaitu kebenaran (truth), informativeness, dan relevance. Kebenaran lebih menyangkut pada aspek reliabilitas dan kredibilitas sebuah berita. McQuail membagi aspek kebenaran menjadi tiga subaspek, yakni factualness, akurasi, dan completeness. Informativeness lebih berkaitan dengan segala sesuatu yang dapat mempengaruhi kualitas pemahaman dan pembelajaran tentang peristiwa yang terjadi, manusia ataupun benda, sedangkan aspek relevance berkaitan dengan standar kualitas proses seleksi berita (Rahayu, 2006: 9-10).

Sementara ketidakberpihakan dijadikan ukuran kualitas sebuah berita sehingga dapat dijadikan sebagai acuan evaluasi. McQuail membedakan aspek evaluatif ini menjadi dua, yakni balance dan netralitas. Balance lebih berhubungan dengan seleksi atau penghilangan fakta-fakta yang mengandung nilai atau ekspresi point of view mengenai apa yang dianggap sebagai 'fakta' oleh pihak-pihak yang terkait dalam perdebatan. Sedangkan netralitas lebih berhubungan dengan presentasi fakta (Rahayu.ed. 2006: 10-11).

Selain aspek teknikalitas, ukuran berita berkualitas dapat mengacu pada lima (5) dimensi ${ }^{6}$, yaitu: 1) Kedalaman substansif, 2) Kualitas data, 3) Alternatif Kebijakan, 4) Kualitas sumber, 5) Efek Kepublikan.

\footnotetext{
${ }^{5}$ Output Program “Jurnalisme Publik di Media Online Indonesia” Digi-Journalism. UGM. 2016

${ }^{6}$ Output Program “Jurnalisme Publik di Media Online Indonesia” Digi-Journalism. UGM. 2016
} 
Diterbitkan oleh Program Studi IImu Komunikasi

Universitas Ahmad Dahlan Yogyakarta

\section{Konsep Popular News}

Salah satu hal yang membedakan media massa konvensional dan media online adalah pada Unlimited Space dimana jurnalistik online memungkinkan halaman tak terbatas. Media online juga memungkinkan Audience Control yang menjadikan pembaca lebih leluasa memilih berita/informasi. Dari kedua karakter tersebut, menghadirkan kondisi dimana dalam waktu yang singkat, media online dapat menyuguhkan begitu banyak berita dalam hitungan menit bahkan detik. Meski demikian, pembaca memiliki keleluasaan untuk memilih berita mana yang ingin mereka baca.

Semakin banyak klik yang diberikan pembaca terhadap satu topik berita, maka akan menjadikan berita tersebut sebagai berita paling populer atau terpopuler. Label berita populer ini diberikan oleh media online untuk menunjukkan informasi yang dianggap pembaca sebagai satu berita yang paling banyak dibaca atau menarik. Topik berita terpopuler di tiap media biasanya berbeda beda dan tidak bergantung pada satu isu besar yang sama. Meskipun dalam momen-momen tertentu, berita terpopuler seringkali merupakan representasi satu peristiwa besar yang terjadi secara masif.

\section{Komparasi Quality News dan Popular News}

Sebagai sebuah gambaran kunci yang menitikberatkan pada persoalan antara quality journalism dan popular news, terdapat beberapa indikator yang dapat mempertajam perbandingan keduanya yakni pada aspek pemilihan isu, kedalaman isu, teknik penyajian, dan diksi yang digunakan dalam setiap penerbitan berita.

Tabel 1. Komparasi Quality Journalism dan Popular Journalism

\begin{tabular}{|c|l|l|l|}
\hline No & Indikator & Quality/public journalism & Popular journalism \\
\hline 1 & Pilihan isu & $\begin{array}{l}\text { Menyangkut kepentingan } \\
\text { orang banyak (politik, } \\
\text { ekonomi, sosbud, hukum dll) }\end{array}$ & Isu-isu hiburan dan personal \\
\hline 2 & Kedalaman isu & $\begin{array}{l}\text { Lebih mendalam atau } \\
\text { setidaknya menjawab } \\
\text { pertanyaan mendasar dari } \\
\text { satu peristiwa }\end{array}$ & $\begin{array}{l}\text { Lebih bersifat permukaan dan } \\
\text { mengulang-ulang hal yang } \\
\text { dianggap sensasional }\end{array}$ \\
\hline 3 & Teknik penyajian & $\begin{array}{l}\text { Serius, berbasis peristiwa } \\
\text { dan ditopang kasus atau } \\
\text { data agregat }\end{array}$ & $\begin{array}{l}\text { Personalisasi, dramatisasi } \\
\text { Relevan dengan } \\
\text { isu/peristiwa }\end{array}$ \\
\hline 4 & Narasumber & $\begin{array}{l}\text { Acak, seringkali tidak relevan } \\
\text { dengan peristiwa, mengejar } \\
\text { sosok/komentar sensasional }\end{array}$ \\
\hline 5 & Diksi & Standar & Dramatik, emosional \\
\hline
\end{tabular}




\section{Melacak Trend Pemberitaan Media Online}

\section{Trend Isu Pemberitaan Media Online}

Pemilihan isu dalam satu pemberitaan menjadi satu kunci penting inti informasi yang akan dikonsumsi publik. Pemilihan isu seringkali pula mempengaruhi persepsi pembaca terhadap satu peristiwa dan pada level yang lebih tinggi menunjukkan ideologi media massa. Dimana satu peristiwa yang sama bisa memberikan banyak pilihan bagi media untuk mengangkat sudut pandangnya. Disinilah nilai penting satu isu diangkat ke permukaan terutama karena apa yang dipilih media untuk disampaikan ke publik, bisa jadi merupakan referensi bagi pembaca.

Isu sendiri juga perlu dibungkus dengan kedalaman atau kelengkapan informasi, sehingga tidak menimbulkan kesalahan persepsi publik dalam menangkap satu peristiwa. Kedalaman juga memberikan alternatif bagi masyarakat untuk melihat satu peristiwa secara lebih luas dan menyeluruh atau tidak hanya dari satu sisi saja melainkan cover all sides.

Hal tersebut diatas juga tidak lepas dari bagaimana teknik penyajian informasi di media massa yang idealnya tidak hanya menyangkut aspek personal dan dramatik saja, melainkan harus berbasis isu dengan sumber data yang lengkap. Ini didukung pula dengan pemilihan narasumber yang relevan sesuai dengan kompetensinya pada satu bidang yang berkaitan dengan isu yang diangkat, serta diksi yang tidak melebih-lebihkan satu hal. Beberapa konsep kunci akan digunakan untuk menelaah lebih jauh diantaranya mengenai: berita hiburan, personalisasi, dramatisasi, popular news, quality news, Issue-Policy Based News dan Investigative News.

\section{Kategori Pemberitaan Media Online}

Selain kategori quality news dan Popular News, beberapa konsep kunci untuk mengkategorikan pemberitaan di media online diantaranya:

\section{a. Issue-Policy Based News}

Kebijakan pemerintah atau pemangku kepentingan yang berdampak luas bagi masyarakat merupakan suatu topik yang memiliki nilai berita. Secara umum kejadian yang mempunyai nilai berita atau layak berita mengandung satu atau beberapa unsur berikut ini: significance, magnitude, timeliness, proximity psikografis, proximity geografis, prominence, dan human interest (Siregar, 1998: 27). Aspek significance atau penting dan magnitude atau berdampak luas, biasanya merupakan nilai dari berita berbasis isu atau kebijakan. Pemberitaan berbasis kebijakan biasanya memiliki dampak yang luas bagi publik dan seringkali menuai pro maupun kontra. Issue-Policy Based News dalam pemberitaan di media online biasanya menjadi berita yang menduduki posisi puncak atau dikategorikan sebagai Headline News. Berita utama juga merupakan cerminan ideologi satu media dalam melihat suatu peristiwa. Penempatan satu berita sebagai headline news juga menjadi salah satu pancingan media dalam menarik klik pembaca. Isu ini sangat mudah untuk dikembangkan karena bisa digali lebih jauh dari berbagai sudut pandang narasumber yang beragam. 
Diterbitkan oleh Program Studi IImu Komunikasi

Universitas Ahmad Dahlan Yogyakarta

\section{b. Investigative News}

Investigasi merupakan salah satu metode peliputan berita dengan menggali secara mendalam (in-depth), melakukan pengumpulan data, informasi dan temuan lainnya mengenai suatu peristiwa yang masih menjadi misteri, belum terungkap atau memerlukan penelusuran, sebagai satu upaya untuk membuktikan peristiwa dan menarik kesimpulan atas rangkaian temuan dan susunan kejadian.

Peliputan investigasi lazim dilakukan di media cetak maupun televisi dengan penyampaian berita secara menyeluruh dan lengkap. Metode ini memerlukan waktu yang lebih panjang dalam menghasilkan satu pemberitaan dibandingkan metode peliputan berita pada umumnya. Pasalnya terdapat riset untuk menghasilkan data, informasi dan argumen dari multi narasumber yang wajib dicantumkan untuk menghasilkan satu liputan yang komprehensif.

Pada era teknologi informasi saat ini, metode liputan investigasi juga merambah dalam dunia jurnalistik online. Namun sedikit berbeda dengan media cetak maupun elektronik, penyajian liputan investigasi di media online tidak sepenuhnya dipaparkan dalam satu berita utuh. Tipikal media online yang menyajikan berita secara cepat dan padat menjadikan penyajian liputan investigasinya dpotong menjadi beberapa bagian berita.

Model peliputan investigasi di media online tetap menggunakan prinsip-prinsip liputan investigasi termasuk ketika harus menyembunyikan identitas narasumber atau korban yang dirahasiakan. Namun jika dilihat dari model penyajian beritanya, media online seringkali menggunakan fasilitas hyperlink atau tautan untuk menyajikan berita yang terkait. Pada prinsipnya, meskipun berita online merupakan berita yang disajikan lebih singkat dan menjadi satu berita yang berdiri sendiri, namun fasilitas hyperlink ini memudarkan anggapan bahwa media online tidak bisa menyajikan liputan mendalam maupun investigatif. Kedua hal tersebut tetap bisa dijalankan, namun dengan model dan modifikasi yang berbeda sesuai dengan karakteristik medianya.

\section{c. Berita Hiburan}

Dalam ranah jurnalistik, kita lazim mengenal dua jenis berita di media massa yakni Straight News/Hard News atau berita keras dan Soft News atau berita ringan. Straight News disebut pula sebagai berita hangat yang memiliki arti penting bagi khalayak karena biasanya berisi kejadian terkini, baru saja terjadi atau sedang terjadi. Sementara soft news biasanya dianggap berita yang kurang penting karena isinya menghibur, meskipun kadang juga memberikan informasi penting.

Di sisi lain, Luwi Ishwara berpendapat bahwa terdapat setidaknya dua jenis berita yakni berita yang terpusat pada peristiwa (event centered news) yang khas menyajikan peristiwa hangat yang baru terjadi dan umumnya tidak diinterpretasikan, dengan konteks minimal, tidak dihubungkan dengan situasi dan peristiwa yang lain. Di sini gagasan utamanya adalah bahwa sebuah topik belum layak untuk menjadi sebuah berita sebelum terjadi sesuatu. Jenis kedua adalah berita yang berdasarkan pada proses (process-centered news) yang disajikan dengan interpretasi tentang kondisi dan situasi dalam masyarakat yang dihubungkan dalam konteks yang luas dan melampaui waktu. ${ }^{7}$

\footnotetext{
${ }^{7}$ Ishwara, Luwi. (2014). Jurnalisme Dasar. Kompas Media Nusantara: Jakarta. Hal 76
} 
Lalu, dimanakah letak dari berita hiburan? Lazimnya dalam kerangka jurnalisme konvensional, ada jurang pemisah yang tegas untuk membedakan antara berita dan hiburan. Dalam konteks masa itu, berita berkutat pada satu peristiwa yang benar-benar dianggap penting, tegang, serius dan merupakan satu kejadian dengan implikasi besar. Namun dalam perkembangan jurnalisme masa kini, berita menjadi lebih cair dan tidak hanya sekedar menyuguhkan peristiwa secara kaku. Pada akhirnya, berita bukan hanya sekedar memberikan informasi saja namun juga mampu menghibur. Jika dikategorikan pada jenis berita, maka berita menghibur atau berita hiburan masuk dalam kategori soft news atau berita ringan karena unsur penting didalamnya tidak terlalu ditonjolkan. Berita ini juga mengandung interpretasi yang dihubungkan dengan konteks yang luas.

Dalam perkembangannya berita hiburan berubah menjadi satu makna yang lebih sempit yang kebanyakan hanya dikaitkan dengan aktivitas para selebriti atau orang ternama. Inilah yang pada akhirnya berkembang menjadi infotainmentdimana para pegiatnya (jurnalis infotaintment) mengklaim jenis berita ini sebagai perpaduan antara informasi dan entertaintment (hiburan). Meski terdapat dua pendapat yang berseberangan yang menganggap infotainment bukanlah bagian dari karya jurnalistik karena seringkali hanya menonjolkan sensasionalisme, gosip dan sisi personal selebriti semata yang tidak memiliki dampak bagi kepentingan publik. Sementara di satu sisi, ada yang menilai bahwa infotaintment merupakan kegiatan jurnalistik yang meliputi mencari, mengolah dan menyebarluaskan satu informasi serta memenuhi unsur formulasi berita $5 \mathrm{~W}+1 \mathrm{H}$ (Who, What, Why, Where, When, How).

Pada dasarnya, berita hiburan bukan merupakan satu berita yang perlu kita lihat sebelah mata. Kenyataanya, masyarakat kita tidak sedikit yang tertarik dengan berita yang menghibur. Bahkan berita hiburan dianggap sebagai pelepas jenuh akan peristiwa-peristiwa menegangkan yang banyak dilaporkan dalam pemberitaan. Namun demikian, kita tetap perlu mengkritisi berita hiburan yang kini menjadi trend di berbagai ranah media massa termasuk media online. Pertanyaan yang muncul disana adalah, adakah kepentingan publik yang seharusnya disampaikan oleh media massa dalam berita hiburan tersebut?

\section{d. Personalisasi}

Penonjolan aspek personal dari satu narasumber, kerap menghiasi pemberitaan media online kita. Tema-tema pemberitaan diangkat berdasarkan sosok pribadi seseorang yang dianggap "seksi" atau memiliki daya tarik secara prominence. Sebagai satu unsur berita, prominence mencakup orang atau tokoh yang dikenal oleh publik karena kemakmurannya, posisi sosialnya, prestasinya atau publisitas sebelumnya baik itu positif maupun

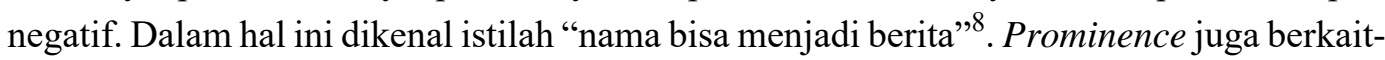
an dengan orang-orang atau individu-individu terkemuka. Ukuran individu yang memiliki prominenceadalah individu yang memiliki pengaruh luas dalam masyarakat. ${ }^{9}$

\footnotetext{
${ }^{8}$ Rolnicki, Tom E. Down Tate. Sherri A Taylor. (2008). Pengantar Dasar Jurnalisme. Kencana: Jakarta. Hal.11

${ }^{9}$ Rahayu. (ed.). 2006. Menyingkap Profesionalisme Surat Kabar di Indonesia. Cetakan Pertama. Jakarta: Krayon Grafika.
} 
Diterbitkan oleh Program Studi IImu Komunikasi

Universitas Ahmad Dahlan Yogyakarta

Personalisasi dalam pemberitaan pada dasarnya bukan merupakan hal yang sepenuhnya salah. Namun juga bukan berarti setiap pemberitaan hanya menonjolkan sisi personal seseorang saja karena justru bisa menjebak media dalam sesnsasionalisme atau gosip. Menurut Rahayu (2006) sensasionalismedapat dilihat melalui dua hal yaitu, terdapat personalisasi yang melihat individu tertentu sebagai aktor utama atau aktor tunggal yang paling berpengaruh dalam sebuah peristiwa. Serta dramatisasi yaitu penulisan berita yang bersifat hiperbolik dan melebih-lebihkan sebuah fakta dengan maksud menimbulkan efek dramatis.

Selain sensasional, media yang hanya menonjolkan personalisasi juga lupa akan kepentingan publik dari pemberitaannya. Berbagai sisi narasumber dikorek hingga hal-hal yang pada dasarnya tidak memiliki implikasi nyata bagi apa yang dibutuhkan masyarakat. Media online akhirnya juga sering terjebak pada clickbait journalism atau jurnalisme umpan balik yang seringkali menggunakan judul sensasional sebagai trik menjaring klik pembaca.

\section{e. Dramatisasi}

Mendramatisasi realitas berarti melebih-lebihkan kenyataan dari yang sebenarnya. Ini bisa dilakukan dengan menggunakan bahasa-bahasa yang mempunyai efek dramatik ataubiasanya dengan menggunakan majas hiperbola. Dalam pemberitaan media, dramatisasi dapat dideteksi dari pilihan bahasa yang digunakan jurnalis atau media pada pemberitaannya, yakni: ${ }^{10}$

1) Penggunaan Bahasa Hiperbolik

2) Dalam Bahasa Indonesia, dikenal majas hiperbolik yang berarti melebih-lebihkan. Sebagai contoh, sifat tak pernah menerima kekalahan telah mendarahdaging dalam diri politisi kita.

3) Penggunaan Metafor

4) Metafora berarti membandingkan. Dalam dunia jurnalistik, realitas sering diperbandingkan demi menimbulkan efek dramatik. Makna yang terkandung dalam majas metafora adalah suatu peletakan kedua dari makna asalnya, yaitu makna yang bukan mengunakan kata dalam arti sesungguhnya, melainkan sebagai kiasan yang berdasarkan persamaan dan perbandingan. Misalnya, Para politisi sering kali menjadi biang kerok kegaduhan dibandingkan sebagai penyelesai masalah yang bisa diandalkan.

Meski demikian, efek dramatisasi dalam pemberitaan bisa dilakukan oleh media massa dengan membangun situasi bagi pembaca atau khalayak dengan cara menjejali pembaca dengan topik tertentu sehingga seolah topik tersebut merupakan peristiwa penting dan besar yang harus terus dikonsumsi khalayak. Padahal, realitas yang seolah dramatis tersebut sebenarnya dengan sengaja tengah dibangun oleh media. Sayangnya, topik atau realitas yang dibangun media tersebut seringkali tidak merepresentasikan situasi yang cukup penting bagi khalayak atau berdampak pada kepentingan publik. Dalam pratik jurnalisme online misalnya, seringkali pemberitaan atau topik yang dibahas secara terus-

${ }^{10}$ Poentarie, Emmy. (2015). Bahasa Sensasional dalam Pemberitaan Media. Jurnal Widyaparwa, Volume 43, Nomor 2, Desember 2015. 
menerus adalah mengenai suatu hal yang berkaitan dengan ranah privat seseorang atau bahkan pada isu permukaan yang tidak memiliki manfaat apapun bagi masyarakat.

\section{Kesimpulan}

Spirit yang diusung dalam jurnalisme publik adalah perpaduan ideal untuk menyajikan sebuah berita yang berkualitas (quality news) sekaligus populer (popular news). Komparasi keduanya menunjukkan, pada aspek pemilihan isu, quality journalism lebih mengangkat pada isu-isu yang memiliki aspek kemanfaatan pada kepentingan publik. Sekalipun kemanfaatan pada individu sangat relatif, namun nilai penting satu peristiwa untuk diketahui publik lebih tinggi dibandingkan dengan apa yang disampaikan pada popular journalism. Gambaran umumnya adalah pada popular journalism misalnya, pengemasan satu topik berita lebih ditekankan pada sisi personal narasumber yang jika ditelaah lebih mendalam bukan lagi merupakan ranah publik tapi sudah merujuk pada privacy seseorang.

Sementara dari aspek kedalaman isu yang disajikan, quality journalism lebih memiliki kelengkapan sisi, baik dari narasumber maupun informasi yang akan disampaikan. Lengkap dalam hal ini bukan berarti harus menyajikan banyak narasumber pada satu tubuh berita. Pasalnya karakter tersebut saat ini lebih banyak dimungkinkan pada media cetak dan media online memiliki kekhasannya sendiri dalam menyajikan informasi (kelengkapan informasi/narasumber disampaikan dalam hyperlink atau berita terkait). Isu yang dilemparkan ke publik dalam quality journalism dikupas lebih lengkap dan mendalam atau setidaknya menjawab pertanyaan mendasar dari inti peristiwa yang akan disampaikan. Hal ini bisa dilihat misalnya dari konsistensi antara judul dan isi berita. Di sisi lain, popular news mengangkat satu isu tertentu namun banyak pada tataran permukaan saja. Kedalaman yang diupayakan masih terjebak pada dramatisasi satu peristiwa dan bukan untuk menyajikan informasi secara proporsional dan utuh.

Dari sisi teknik penyajian berita, quality journalism menggunakan model pembahasan lebih serius dan berbasis isu yang memiliki sumber data relevan. Sementara pada popular journalism banyak mengangkat aspek persoalisasi narasumber atau individu, sensasionalisme dan dramatisasi. Berita hiburan, seringkali hanya melempar satu isu personal yang dikait-kaitkan dengan hal-hal yang tidak memiliki bobot publik, misalnya, kematian seseorang dengan klenik, tanggal lahir dikaitkan kesuksesan, firasat dari satu kejadian dan lainnya.

Quality journalism juga berupaya untuk menyajikan narasumber yang memiliki relevansi dengan peristiwa atau topik yang dibahas. Minimal ia memiliki kompetensi yang berkaitan dan kredibel. Di satu sisi, popular news tentu mengutamakan sisi ketenaran seorang narasumber khususnya kalangan selebritas yang seringkali tidak memiliki kompetensi untuk menjadi sumber informasi satu isu tertentu. Dalam popular journalism pemilihan narasumber juga cenderung acak, yang penting namanya menjual dan dikenal publik.

Pemilihan kata dalam pemberitaan juga memiliki aspek penting terhadap persepsi yang diterima publik atas satu peristiwa. Jurnalisme berkualitas menggunakan bahasa yang lebih standar atau sesuai dengan kaidah bahasa yang baik dan cenderung formal. Sementara 
Diterbitkan oleh Program Studi IImu Komunikasi

Universitas Ahmad Dahlan Yogyakarta

dalam berita hiburan, banyak diksi yang lebih dramatis dan tak jarang terlalu banyak label yang disematkan jurnalis dalam pemberitaanya. Misalnya, menganggap atau memberi label satu orang tertentu dengan sebutan 'kejam', 'cantik', 'sabar' dan lainnya. Diksi dalam popular news khususnya pada judul juga seringkali disengaja memancing pembaca, sehingga menggunakan kata-kata yang dramatis, bahasa alay dan lainnya.

Meski bukan merupakan hal yang sepenuhnya salah, isu populer atau berita hiburan pada dasarnya bisa dikemas menjadi berita yang berkualitas. Indikator minimal diatas setidaknya bisa menjadi sebuah patokan bahwa pada dasarnya kegiatan jurnalistik harus bermuara pada apa yang menjadi kepentingan publik. Dimana kondisi tersebut dapat dicapai tentunya dengan tidak mengabaikan aspek-aspek teknis sebagai satu hal mendasar, tidak lengah dengan substansi informasi yang akan dikonsumsi publik, yang tentunya harus relevan pula dengan kepentingan publik.

\section{Daftar Pustaka}

Anom, E. (2011), “WajahPers Indonesia 1999-2011”, Jurnal Komunikasi, Malaysian Journal of Communication, 27(1): 101-114.

Ermanto, 2005, MenjadiWartawan Handal dan Profesional, Citra Pena, Yogyakarta.

Kriyantono, Rachmat, 2006, Teknik Praktis Riset Komunikasi, Kencana Prenada Media, Jakarta.

Kusumaningrat, Hikmat dan Purnama Kusumaningrat, 2005, Jurnalistik: Teori dan Praktik, Remaja Rosdakarya, Bandung.

Mulyana, Deddy, 2004, Metodologi Penelitian Kualitatif, PT Remaja Rosdakarya, Bandung.

Moleong, Lexy, 1990, Metodologi Penelitian Kualitatif, PT Remaja Rosdakarya, Bandung.

Moleong, Lexy, 2002, Metodologi Penelitian Kualitatif, PT Remaja Rosdakarya, Bandung.

Noor, Juliansyah, 2013, Metodologi Penelitian: Skripsi, Tesis, Desertasi dan Karya Ilmiah, Kencana, Jakarta.

Sumadiria, AS Haris, 2005, Jurnalistik Indonesia: Menulis Berita dan Feature, Simbiosa Rekatama Media, Bandung.

Ishwara, Luwi. (2014). Jurnalisme Dasar. Kompas Media Nusantara: Jakarta.

Kovach, Bill; Tom Rosenstiel. 2012. Blur: Bagaimana Mengetahui Kebenaran di Era Banjir Informasi. Dewan Pers: Jakarta.

Nasrullah, Rulli. 2016. Media Sosial: Perspektif Komunikasi, Budaya dan Sosioteknologi. Simbiosa Rekatama Media: Bandung.

SabilIskandar, Dudi; Rini Lestari. 2016. Mitos Jurnalisme. PenerbitAndi: Yogyakarta.

Rolnicki, Tom E. Down Tate. Sherri A Taylor. (2008). Pengantar Dasar Jurnalisme. Kencana: Jakarta. Hal 11

Rahayu. (ed.). 2006. Menyingkap Profesionalisme Surat Kabar di Indonesia. Cetakan Pertama. Jakarta: Krayon Grafika.

Siregar, Ashadi. 1999. Media dan Gender: Perspektif Gender atas Industri Surat Kabar Indonesia. Yogyakarta: LP3Y. 
Output Program: Jurnalisme Publik untuk Media Online di Indonesia, Digi-Journalism UGM, Yogyakarta

http://digi-journalism.or.id/truth-in-the-making/ akses 7 Agustus 2016 